\title{
BAYINDIR KIZILKEÇİLİ KÖYÜNDE RUMİ 1320 YILI SON NÜFUS TAHRİİ
}

\author{
Necat ÇETIN*
}

\begin{abstract}
ÖZ
Kızılkeçilililer, Salur boyundandır. Anadolu'da pek çok kendi adlarına köy kurmuşlardır. Bugün Çanakkale, Balıkesir ve İzmir Bayındır İlçesine bağlı Kızılkeçili adlı köyler bulunmaktadır. Bayındır Kızılkeçili köyü Bayındır İlçesine $45 \mathrm{~km}$ uzaklıkta olup 1530 yılı tapu tahrir defterinde köy 16 hane, 3 mücerret, bulunmaktadır. Toplanan yıllık vergi yani hasıl: 4386 akçedir. Köyde en son Osmanlı nüfus tahriri 1316 tarihli nizamnameye göre 8.7.1320 tarihinde yapılmıştır. $\mathrm{Bu}$ tahririn en önemli özelliği bugünkü nüfus belgelerimize dayanaklık yapmasıdır. Tahrirde toplam 58 hanede toplam kişi sayısı 328 tespit edilmiştir. Bütün hane reisleri erkektir. Yazımı yapılan 328 kişiden 159 kişi erkek (\% 48.47), 169 kişisi (\%51.52 ) ise bayandır. Yazımı yapılan 328 kişiden 144 kişi (\% 43.90) evli, 165 kişi (\% 50.30) bekâr ve 19 kişisi (\% 5.80) duldur. Bazı hanelerin kayıtları "kapalı kayıt" konumundadır (\% 24.13). Bazı hanelerin kaydı farklı idari birimlere alınmıştır. Köye sadece 1 hane başka idari birimden nakil gelmiştir.
\end{abstract}

Anahtar Kelimeler: Kızılkeçeli Aşireti, Bayındır, Nüfus Kaydı, Nüfus Tahriri, Kızılkeçeli Köy.

\section{The Last Census (1320 ah) in the Village of Kızlkeçeli in Bayindır}

\begin{abstract}
Kızılkeçililis are from Salur tribe. They established many villages on behalf of themselves. Today, thevillages called as Kızılkeçili have been in Çanakkale, Balıkesir, Bayındır of Izmir. The village of Kızılkeçili in Bayındır is away $45 \mathrm{Km}$ from center of the county. There was 16 houses, 3 tax exempt people in dated 1530 land registry (tapu tahrir defteri). Total tax is 4386 coins. The last census in the village was made on 8th July 1320AH according to $1316 \mathrm{AH}$ dated law. The most significant feature of this census is its constituting a basis to today's population registry documents. It was determined 328 people in 58 houses and all heads of family were men. $159(\% 48.47)$ of 328 people are men, $169(\%$ 51.52 ) of them are women. 144 (\% 43.90) people are married, 165(\% 50.30) people are single, $19(\% 5.80)$ people are widow. Some houses' records are closed record $(\%$ 24.13). Some families' records have been taken to different administrative units. Only house came from other place.
\end{abstract}

Keywords: Kızılkeçeli Tribe, Bayındır, Population Registry, Census, Kızılkeçeli Village.

\footnotetext{
*Uzman Tarih Öğretmeni-Araştırmacı Torbalı İzmir, ncetin1963@gmail.com
} 


\section{Necat ÇETÍN}

\section{GİRIŞ}

Türklerin Anadolu'ya 1071 Malazgirt Savaşı'ndan önce de girdiği bilinmektedir. 1071'den sonra da Anadolu'ya yoğun bir şekilde Türk göçü olmuştur. Kızılkeçili aşireti de diğer birçok Türk boy ve aşiretleri ile birlikte Anadolu'ya gelmiş olup değișik yerlere dağılmışlardır. Kızılkeçili cemaatleri Oğuzların Üçok kolunun Dağ Han'ın soyundan gelmektedir. Salur boyuna mensupturlar.

Boyun adı Kaşgarlı Mahmud'un 'Divan-1 Lügati't-Türk'ünde ( XI. Yüzyıl ) Salgur diye yazılmış, XII ve XIII. Yüzyıl kaynaklarında aynı imla ile bazan da Şalgur şeklinde belirtilmiş, XIV. yüzyıldan itibaren bu ad Salur biçimini almıştır. Reşidüddin'e göre Salur kelimesi 'Nerede olsa kılıç ve topuzu iş görür' anlamına gelmektedir. ${ }^{1}$

Ayrıca Kızılkeçili cemaatleri, Kızılca Keçilü cemaatleri grubuna bağlıdırlar. Öte yandan Kızılkeçili cemaatleri Çorum Sancağı'nda, Biga Sancağı'nın Ezine Kazası'nda, Kars-1 Maraş Sancağı'nda ve Saruhan Sancağı'nda bulunmaktadır.

Kızılkeçili aşireti bir Yörük aşireti olup adını güttükleri keçilerin renginden almıştır. Öte yandan Anadolu'nun bazı yerlerinde halen Kızılkeçili köyleri bulunmaktadır. Bunlar aşağıda verilmiştir.

Birinci olarak Çanakkale ilinin merkez ilçesinin merkez bucağına bağlı bir yerdir. İkincisi Çanakkale ili, Gülpınar bucağına bağlı bir yerleşim birimidir. Üçüncüsü Balıkesir ili, Edremit ilçesi, merkez bucağına bağlı bir yerleşim birimidir. Dördüncüsü İzmir ili, Bayındır ilçesi, merkez bucağına bağlı bir yerleşim birimidir. Beşinci olarak da Kızılkeçili, Çanakkale ilinin Ayvacık ilçesine bağlı bir köydür.

Kızılkeçili aşiretinin 15 . ve 16. yüzyıldaki tapu tahrir defterlerindeki kayıtları aşağıdaki tablodaki gibidir.

\footnotetext{
${ }^{1}$ Faruk Sümer, "Salur", TDV İslam Ansiklopedisi, Cilt: 36, TDV Yayınları, Ankara 2009, 57.
} 
Bayındır Kızılkeçili Köyünde Rumi 1320 Yılı Son Nüfus Tahriri

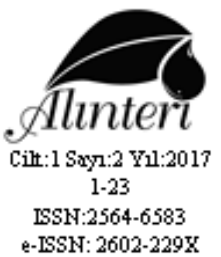

Tapu tahrir defterlerinde Kızılkeçili cemaati ile ilgili kayıtlar ${ }^{2}$

\begin{tabular}{|c|c|c|c|c|c|c|c|c|}
\hline $\begin{array}{l}\text { CEMAAT } \\
\text { ADI }\end{array}$ & TAİFE & GRUP & BOY & S & $\mathrm{H}^{3}$. & M. & YURDU & $\begin{array}{l}\text { SAN }^{4} .^{-} \\
\text {NAH }^{5} \text {. }\end{array}$ \\
\hline $\begin{array}{l}\text { Kuzıl } \\
\text { Keçilü } \\
\text { Cemaati }\end{array}$ & - & $\begin{array}{l}\text { Kızılca Keçilü } \\
\text { Cemaati }\end{array}$ & Salur & $\mathrm{T}$ & 5 & 0 & Kızıl Keçilü k. & $\begin{array}{l}\text { Çorum S.- } \\
\text { Emlak } \\
\text { Divanı }^{6}\end{array}$ \\
\hline $\begin{array}{l}\text { Kızıl } \\
\text { Keçilü } \\
\text { Cemaati }\end{array}$ & - & $\begin{array}{l}\text { Kızılca Keçilü } \\
\text { Cemaati }\end{array}$ & Salur & $\mathrm{T}$ & 82 & 102 & - & $\begin{array}{l}\text { Biga S.- } \\
\text { Ezine } \\
\text { Kaz. }^{7}\end{array}$ \\
\hline $\begin{array}{l}\text { Kizıl } \\
\text { Keçilü } \\
\text { Cemaati }\end{array}$ & - & $\begin{array}{l}\text { Kızılca Keçilü } \\
\text { Cemaati }\end{array}$ & Salur & $\mathrm{T}$ & 18 & 21 & Bey Ağar k. & $\begin{array}{l}\text { Biga S.- } \\
\text { Ezine } \\
\text { Kaz. }^{8}\end{array}$ \\
\hline $\begin{array}{l}\text { Kuzıl } \\
\text { Keçilü } \\
\text { Cemaati }\end{array}$ & - & $\begin{array}{l}\text { Kızılca Keçilü } \\
\text { Cemaati }\end{array}$ & Salur & $\mathrm{T}$ & 9 & 3 & $\begin{array}{l}\text { Susuk k. Yukuk } \\
\text { k.?Çanad Pınarı } \\
\text { k. }\end{array}$ & $\begin{array}{l}\text { Biga S.- } \\
\text { Ezine } \\
\text { Kaz. }^{9}\end{array}$ \\
\hline $\begin{array}{l}\text { Kızıl } \\
\text { Keçilü } \\
\text { Cemaati }\end{array}$ & - & $\begin{array}{l}\text { Kızılca Keçilü } \\
\text { Cemaati }\end{array}$ & Salur & $\mathrm{T}$ & 2 & 6 & $\begin{array}{l}\text { Süleyman } \\
\text { (Dündarlı) k. }\end{array}$ & $\begin{array}{l}\text { Biga S.- } \\
\text { Ezine } \\
\text { Kaz. }^{10}\end{array}$ \\
\hline $\begin{array}{l}\text { Kuzıl } \\
\text { Keçilü } \\
\text { Cemaati }\end{array}$ & $\begin{array}{l}\text { Maraş } \\
\text { Yörükleri }\end{array}$ & $\begin{array}{l}\text { Karamanlu } \\
\text { (Kızıl Keçilü } \\
\text { Cemaati) }\end{array}$ & Salur & $\mathrm{T}$ & 86 & 34 & - & $\begin{array}{l}\text { Kars-1 } \\
\text { Maraş S. } \\
\text { (Adana- }_{\text {Kadirli) }}{ }^{11}\end{array}$ \\
\hline $\begin{array}{l}\text { Kızıl } \\
\text { Keçilü } \\
\text { Yörükleri } \\
\text { Cemaati }\end{array}$ & $\begin{array}{l}\text { Mukataahane } \\
\text { Yörükleri }\end{array}$ & $\begin{array}{l}\text { Kızılca Keçilü } \\
\text { Cemaati }\end{array}$ & Salur & $\mathrm{T}$ & 6 & 8 & - & $\begin{array}{l}\text { Saruhan S.- } \\
\text { Nif Kaz. }\end{array}$ \\
\hline
\end{tabular}

\footnotetext{
Ankara 2009.

${ }^{3}$ Hane

${ }^{4}$ Sancak.

${ }^{5}$ Nahiye

${ }^{6}$ BOA, TD, nr. 444, s.54, sene 927 (1520-21).

${ }^{7}$ TKA, TD, nr. 79, vr. 156a-157a, sene 982 .

${ }^{8}$ TKA, TD, nr. 79, vr. 157a sene 982 (1574-75).

${ }^{9}$ TKA, TD, nr. 79, vr. 157a sene 982 (1574-75)

${ }^{10}$ TKA, TD, nr. 79, vr. 157a, sene 982 (1574-75).

${ }^{11}$ TKA, TD, nr. 168, s. 55b-56a, sene 971.

${ }^{12}$ TKA, TD, nr. 125, vr. 67b, sene 983 (1575-76).
}

${ }^{2} \mathrm{Bu}$ tablo Yusuf Halaçoğlu'nun yayınladığı Anadoluda Așiretler Cemaatlar Oymaklar (1453-1650) kitabından geniș ölçüde faydalanılarak hazırlanmıștır. Bakınız: Yusuf Halaçoğlu, Anadolu'da Aşiretler Cemaatlar, Oymaklar (1453-1650), Cilt: 6, TTK Basımevi, 


\section{OSMANLI DEVLETINDE İLK NÜFUS SAYIMI}

Osmanlı Devleti nüfus sayımına büyük önem vermiş ve bunu asırlarca toprak yazımı dolayısıyla yapmıştır. ${ }^{13}$ Osmanlı Devleti yeni fetih ettiği memleketlerin arazisini tescil, toprağın mülkiyet ve tasarruf sistemini belirlemek ve vergi miktarlarını tayin ve tespit etmek amacıyla düzenli olarak bu sayımları yapmıştır. Bu sayımlara tahrir denirdi. Tahrirlerin otuz senede bir yapılması kanunla sabitti. Bununla beraber bazen bu süre uzadığı gibi, cülus, bir bölgede toprağa tasarruf edenler arasındaki anlaşmazlıklar, halkın vergilerin adaletsizliğinden fazlaca şikâyet etmeleri, göçler ve salgın hastalıklardan dolayı kısa bir zamanda meydana gelen büyük nüfus değişiklikleri gibi sebeplerden dolayı bu süre kısalır, tahrirler yeniden yapılırdı. ${ }^{14}$ Osmanlı Devleti'nin kuruluşundan itibaren "memleket tahriri" adı altında yapılan bu yazım ve sayımlardaki temel amaç asker ve vergi toplamaktı. ${ }^{15} \mathrm{Bu}$ tahrirlerin başlayış ve bitiş tahrirleri ihtilaflı bir konudur. Ebül'ula Mardin'e göre ilk tahrir Sultan Orhan (1326-1389) dönemine aittir. Ö.Lütfi Barkan'a göre ise, ilk tahrir Sultan Murat döneminde (1360-1389) yapılmıştır. Son tahrir ise Netayic'ül Vukuat müellifi Mustafa Paşa'ya göre II. Selim (1566-1574) devrinde yapılmıştır. Barkan'a göre ise son tahrir III. Murat (1574-1595) devrinde yapılmıştır. Hammer ise, III. Murat devrinden sonra da tahrir yapıldığını belirtmiştir. ${ }^{16}$

Tahrirler sonucunda tutulan defterler asker almada ve vergilendirmede başvurulan ana kaynak olması münasebetiyle büyük bir titizlikle saklanmıştır. Ancak devletin yükselme döneminde düzenli bir şekilde yapılan bu tahrirler, duraklama döneminde aksamaya başlamıştır. ${ }^{17} \mathrm{Bu}$ dönemde devlet kurumları asli vazifelerini yerine getiremeyecek bir duruma gelmiş ve bunun neticesinde de "Tahrirler" yapılamaz bir hal almıştır.

II. Mahmut, ülke yönetimini ele aldıktan sonra Osmanlı Devleti'ni dağılma ve çökmekten kurtarmak için yeni düzenlemelere girişmiştir. II. Mahmut içte ve dışta karşılaştığı güçlüklerin üstesinden az da olsa gelince 1826 yılında Yeniçeri Ocağı'nı kaldırıp yerine “Asakir-i Mensure-i Muhammediye" adlı yeni bir ordu kurmuştur. Bu ordunun kurulmasından

\footnotetext{
${ }^{13}$ Enver Ziya Karal, Osmanlı Imparatorluğu'nda İlk Nüfus Sayımı 1831, Ankara 1943, s. 6.

${ }^{14}$ Midhat Sertoğlu, Osmanlı Tarih Lûgatı, Enderun Kitapevi, İstanbul 1986, s. 326-327.

${ }_{15}$ Musa Çadırcı, Tanzimat Döneminde Anadolu Kentlerinin Sosyal ve Ekonomik Yapısı, TTK Basımevi, Ankara 1997, s. 44.

${ }^{16}$ Karal, a.g.e., s. 7.

${ }^{17}$ Halime Doğru, "Osmanlı Devletinde Toprak Yazımından Nüfus Sayımına Geçiş ve Bir Nüfus Yoklama Defteri Örneği”, Anadolu Üniversitesi Fen-Edebiyat Fakültesi Dergisi, C.1, S. 2, Eskişehir 1989, s. 238-241.
} 
hemen sonra ordunun giderleri sorunu ortaya çıkmıştır. Kurulan bu ordunun insan ve mali kaynaklarını tespit etmek amacıyla ülke genelinde Müslüman ve gayr-i müslim bütün erkek nüfusunun sayımının yeniden yapılmasına karar verilmiştir. II. Mahmut döneminde ilk nüfus sayımına İstanbul'da başlanmış ancak 1828-1829 Osmanlı-Rus savaşı münasebetiyle ara verilmek zorunda kalınmıştır. II. Mahmut Osmanl1Rus savaşının bitiminden hemen sonra Anadolu ve Rumeli'de nüfus sayımına başlanmasına karar vermiştir. ${ }^{18} 1830$ yılında yapılan nüfus sayımları ile ilgili olarak toplanan meclis öncelikle sayımların kimler tarafindan yapılması gerektiğine karar vermiş ve uyulacak nizamnameyi hazırlamıştır. ${ }^{19}$ Uzun süredir nüfus sayımı yapılmadığından halkı endişelendirmemek amacıyla sayım memurları din bilginleri arasından seçilmiştir. ${ }^{20} \mathrm{Bu}$ durumun temel sebebi bu sayımın şeriata aykırı bir durum olmadığını halka göstermektir.

1831 nüfus sayımını bütün sayımlardan ayıran en önemli özelliği, bu sayımın ilk genel sayım olmasıdır. Ayrıca Rumeli ve Anadolu'da yapılmış olan bu ve bundan sonraki genel sayımların tam neticeleri hiçbir zaman neşredilememiş olduğuna göre, 1831 nüfus sayımı neticeleri ilk defa olarak umumi efkâra sunulan sayım olması bakımından da büyük önem taşımaktadır. ${ }^{21}$

Sayım sonuçlarının değerlendirilmesi ve bundan böyle nüfus işleriyle uğraşılması içim Ceride Nezareti kurulmuştur. ${ }^{22}$ Sayımda ilk esas olarak din ayrımı göz önüne alınmıştır. Bütün sancak, kaza ve nahiyelerde sadece erkek nüfus sayılmış, nüfus Müslüman ve gayr-1 müslim olmak üzere iki ana gruba ayrılmıştır. Müslüman nüfus kendi içinde yaş durumuna göre ayrılmıştır. Gayr-1 müslimler ise gelir düzeylerine göre âlâ, evsâd ve edna olarak ayrılmıştır. ${ }^{23}$ Müslüman bölgelerinde muhtar bulunan yerlerde muhtarlar, muhtar bulunmayan yerlerde ise imamlar ve ihtiyar meclisleri, gayr-1 müslimlerin bulunduğu bölgelerde ise papazlar ve kocabaşılar muhbir olarak görevlendirilmişlerdir. $\mathrm{Bu}$ yolla tutulan nüfus defterleri İstanbul'a gönderilmiştir. ${ }^{24}$

\footnotetext{
${ }^{18}$ Mahir Aydın, "Sultan II. Mahmut Döneminde Yapılan Nüfus Tahrirleri", Sultan II. Mahmut Reformları Semineri 28-30 Haziran 1989, İstanbul 1990, s. 81.

${ }^{19}$ Çadırc1, a.g.e., s. 45.

${ }^{20}$ Lütfi Tarihi, C. I, Yapı Kredi Yayınları, İstanbul 1999, s. 145.

${ }^{21}$ Karal, a.g.e., s. 13.

${ }^{22}$ Çadırcı, a.g.e., s. 45.

${ }^{23}$ Tacettin Akkuş, Tanzimat Başlarında Balıkesir Kazası (1840-1845), Zağnos Kültür ve Eğitim Vakfi, Balıkesir 2001, s. 14.

${ }^{24}$ Mehmet Esat Sarıcaoğlu, Milli Tarih Açısından Osmanlı Devleti’nde Merkez Taşra İlişkileri, Kültür Bakanlığı Yayınları, Ankara 2001, s. 64.
} 


\section{Necat ÇETÍN}

Sayım sonucu hazırlanan icmal defterine göre 1.988.027 İslam, 366.625 Reaya, 7.143 Kıpti, 5.338 Yahudi, 16.743 ermeni olmak üzere toplam 2.383.876 Anadolu'da; Rumeli'de ise toplam 1.369.766 erkek nüfus tespit edilmiştir. ${ }^{25}$

Osmanlı Devleti'nde 1831 nüfus sayımından sonra başka nüfus sayımları da yapılmıştır. 1844 'te ordunun yeniden düzenlenmesi amacıyla nüfus sayımı yapılmıştır. ${ }^{26} 1847^{\prime}$ de ilk devlet salnamesi çıkmış, 1864 'te vilayet salnameleri yayınlanmaya başlanmıştır. Bilindiği üzere salnameler nüfusla ilgili önemli bilgiler içermektedir. Bu açıdan salnameler Osmanlı nüfus araştırmalarında büyük önem arz etmektedir. 1852'de Rumeli'de, 1856 'da Anadolu'da ve Suriye'de sayımlar yapılmıştır. ${ }^{27} 1890$ yılında yapılan sayımda kadınların da sayıldığını ve ilk kez düzenli bir nüfus kayıt sisteminin kurulduğunu görmekteyiz. Osmanlı Devleti'nde son nüfus sayımına ise 1316 yılında yayınlanan nizamnameye ${ }^{28}$ göre 1903 'de başlanmış bu da ancak 1907'de tamamlanabilmiştir.

\section{İzmir Bayındır İlçesi Kızılkeçeli Köyü}

Bu köyün kuruluşu XIII. asıra kadar geriye gitmektedir. Bayındır'a kırk iki kilometre uzaklıktadır. Bayındır'ın en uzak köyüdür. Köyde okul da bulunmaktadır. Köyde büyükbaş hayvancılık yaygın olup meyvecilik ve zeytincilik de yapılmaktadır. Ayrıca pekmez yapımı da yaygındır. Kızılkeçili Yörüklerinin kurduğu bir köydür. Türkiye'de üç yerde bu isimden köy bulunmaktadır. Köyün kuruluşu kesin olarak belli değildir. 1530 tarihli Anadolu Vilayeti Muhasebe Defterinde "Kızılkeçili" olarak geçmektedir (S.373). Kayda göre köyde toplam 16 hane, 3 mücerret, bulunmaktadır. Toplanan yıllık vergi yani hâsıl: 4386 akçedir. ${ }^{29}$

\subsubsection{Tarihli Kızılkeçili Köyü Son Osmanlı Nüfus Tahririndeki Köy Nüfus Esas Defterinin İncelenmesi}

Bugün idari teşkilat olarak köy olan Kızılkeçili'de muhtarlık arşivinde bulunan bir adet aile kütük defteri kaydına göre son Osmanlı nüfus tahriri 05.08.1320 (Miladi 1904) de yapılmıştır. Defter boyutu 50 $\mathrm{cm}$ X $70 \mathrm{~cm}$ 'dir. Defterde toplam 59 aile kayıtlıdır. Verilen bilgilere göre son 20 - 25 yıldır yer değişiklikleri ve diğer kayıtlar köylerdeki defterlere işlenmemektedir. Deftere önce her nüfus hanesine bir hane numarası verilmiştir.

\footnotetext{
25 Nuri Akbayar, "Tanzimat'tan Sonra Osmanlı Devlet'i Nüfusu“, Tanzimat'tan Cumhuriyete Türkiye Ansiklopedisi, C. 5, s. 1239.

${ }^{26}$ Akbayar, a.g.m., s. 1239.

${ }^{27}$ Karal, a.g.e., s. 10.

${ }^{28}$ Nüfus Sicil Nizamnamesi, Dersaadet 1316.

${ }^{29} 116$ Numarall Muhasebe-i Vilayet-i Anadolu Defteri (937/1530), Başbakanlık Devlet Arşivleri Genel Müdürlüğ̈̈ Yayınları, Ankara 1995.
} 
Asıl Osmanlıca olan defterlerin ilçe nüfus müdürlüğü arşivinde olduğunu öğrendik. Ancak izin verilmediği için 1976 yılında yeni defterlere aktarılan bilgiler bu defterlere yazılmıştır. Defterde hanenin ilk sırasına hane reisinin bilgileri yazılmıştır. Hane reisinin isim ve varsa aile lakabı, baba adı, anne adı, doğum yeri, doğum tarihi, medeni hali, cinsiyeti ve soyadı yazılıdır. İkinci ve diğer sıralarda ise genellikle hane reisinin erkek kardeş, erkek çocuklar, takriben eş veya eşler var ise annesi ve kızlarıyla ilgili bilgiler vardır. Aile kütük defterinin karşı sayfasında ise o kişi ile ilgili doğum, ölüm, evlenme ve yer değiştirme ile ilgili bilgiler bulunmaktadır.

Yapılan ilk nüfus yazımında Kızılkeçili Köyü'nde toplam nüfus hane sayıs 58 'dir. Her haneye bir numara verilmiştir. Bu numaralar bugün kimliklerimizdeki "aile sıra" numaralarımızdır. Hane reisi olan kişinin bazen lakapları verildiği gibi bazen de sadece isim olarak yazılmıştır. Baba ve anne isimleri yazılırken eğer yaşıyor ise direk ismi, yaşamıyor ise isminin başına "ölü” ibaresi vardır.

Doğum yerleri genellikle "Bayındır”dır. Bayındır sınırları içinde doğanlar için ise sadece "Bayındır" yazılmaktadır. İlçe sınırları dışında doğanların doğum yerleri ise özellikle belirtilmektedir. Doğum yılı olarak "Rumi yıl" yazılıdır. Doğum yıllarını miladiye çevirmek için 584 ilave edilmelidir. Yaptığımız çalışmada ekteki köy nüfus özet defterinde de görüleceği üzere bütün veriler özet tablo şeklinde verilmiştir.

Yazımda köyde bulunan 58 hanede toplam kişi sayısı "328"dir. Hane başına ortalama nüfus miktarı ise ( toplam kişi sayısı / hane sayısı=) 328/58:5.65'dir. Tarihi demografi araştırmalarında genellikle hane ortalama nüfus miktarı 4 olarak kabul edilmektedir. Kızılkeçili Köyü'ndeki hane başına ortalama nüfus miktarı bu rakamın çok üzerindedir. Yazımı yapılan hane reislerinin ortalama yaşı “41.29"dur. Yazımda en yaşlı hane reisi Hane no. "19"da kayıtlı olan Bekir oğlu "Çirkinoğlu İbrahim"dir. Yazımda "80" yaşındadır. Hane halkı dokuz erkek beş kadın olmak üzere toplam on dört kişiden oluşmaktadır. Hane bugün "TAŞ" soyadını kullanmakta olup, halk arasında "Savranlar" lakabı ile tanınmaktadır. Yazımda en genç olan kişi ise hane sıra numarası "9" olan Mustafa oğludur. Yazımda hane reisi olarak "7" yaşındadır. Hane halkı bir erkek üç kadın olmak üzere toplam dört kişiden oluşmaktadır. Hane bugün "kapalı kayıt" konumundadır. Yani soyu devam etmemektedir. Hane reislerinin cinsiyeti; 58 hane reisinin hepsi de (\% 100) erkek olup aralarında hiç kadın hane reisi bulunmamaktadır. 


\section{Necat ÇETÍN}

Hane reislerinin defterde bulunan lakapları: Hane ${ }^{30}$ 1-10-11-53 "Hac1", H.2-3-4 "Tahtacioğlu”, H.5 "Başoğlu”, H.6-7-14-15-24-52 "Koca”, H.8-9 "Cura”, H.12-13 "Karabacakoğlu”, H.16-17-18-57 "Deli”, H.19 "Çirkinoğlu”, H.20 "Kolcuoğlu”, H.21-22-48-49-58 "Kara”, H.23 "Kel”, H.25 "Çiloğlan”, H.26 "Sivrioğlu”, H.27-28 "Koçoğlu”, H.29 "Beycanoğlu", H.30 "Çobanoğlu", H.31 "Özçobanoğlu", H.32-33-34 "Çakıroğlu", H.35 "Solakoğlu", 36-37-38 "İmamoğlu", H.39-40-41 "Demircioğlu", H.42-43 "Delibeyoğlu”, H.44 "Hudaycioğlu”, H.45 "Kirlioğlu”, H.46-47 "Karaoğlu”, H.50 “Öksüzoğlu”, H.54-55 "Çiloğlanoğlu”, H.56 "Çağlıŏ̆lu”dur.

Hane reislerinin baba ve annelerinin sağ veya ölü olma durumları, -58 hane reisinin hepsinin de $(\%$ 100) anne ve babası sağdır. Hane reislerinin doğum yerleri; 58 hane reisinin hepsinin de (\% 100) doğum yeri "Bayındır"dır. Hane reislerinin soyadları: 58 hanenin 54 tanesinin (\% 93.10) soyadı defterde kayıtlıdır. 4 tanesinin (\% 6.90) ise soyadı defterde kayıtlı değildir. Bunun nedeni ise bu hanelerin kapalı kayıt olması konumunda veya soyadı almadan önce naklen başka bir idari birime gitmesinden dolayıdır. Hane içi kişi sayısı, yazımda en kalabalık aile H.19 "TAŞ" soyadını taşıyan aile olan hanedir. Yazımda hanede toplam "14" kişi vardır. Yazımda hane içi kişi sayısı en az olan haneler ise "H.36-4858"dir. Bu hanelerde kişi sayısı "2"dir.

Yazımdaki hanelerin su anda idari birimdeki lakapları yerine kullanılan kabile isimleri şunlardır; 1 "İlyas Çavuşlar", H.2 "Koca Yusuflar”, H.3-4 "Tahtalılar- Paşalar”, H.6-7 "Karaoğlan oğulları”, H.8-9 "Çakırlar", H.10-11-53 "Kır İsmailler", H.12 "Ömerler", H.13 "Bacaklar", H.15 "Tozluoğulları", H.16-18 "Topal Hasanlar- Koca Hüseyinler”, H.19 “Savranlar”, H.20 "Kadığulları”, H.21-22 “ Musa Hocalar- Kayışlar", H.23 "Yörük oğulları", H.24 "Kara Osmanlar", H.2542-43-56 "Delibeyler", H.26 "Kara Mehmetler", H.28 "DeğirmencilerKoca Biyıklar", H.30-31 "Kel Çoban- Çobanoğulları", H.32-33-34 "Köseler- Koca Köseler", H.36-37-38 "Topallar- Kara Aliler”, H.39-4041 "Mimarlar- Şer Hasanlar", H.44 "Hedeyciler”, H.45 "Erkırlığulları", H.46-47 "Çamurlar", H.49 "Koca Ahmetler- Çakıcılar", H.50 "Koca Hasanlar- Öksüzler", H.51 "Koca Kirlılar- Kavaslar", H.52-58 "Hafiz Mehmetler- Delibey oğulları", H.54-55 "Hamzalar”dır.

1320 yazımından sonra köy nüfus defterine kayıtlı olan hanelerin lakapları ise şunlardır, H.59 “Çamurlar”dır.1320 yazımındaki hanelerle ilgili açıklamalar; Bazı hanelerin kayıtları halen köy nüfus defterinde "kaydı devam" etmektedir.( \%75.86) Bu haneler şunlardır: H.1 (Kayrak), H.2 (Çiftçioğlu), H.3 (Çengere), H.4 (Cengerek),H.6-7 (Yakın), H.8-9

\footnotetext{
${ }^{30}$ Açıklama: Hane bundan sonra sadece "H." ile gösterilecektir.
} 
(Çatmal1), H.10-11 (Yurt), H.12 (Karabacak), H.13 (Bacak), H.14 (Tozgun), H.16-18 (Yaykın), H.19 (Taş), H.20 (Tülü), H.21-22 (Gökten), H.23 (Saban), H.24 (Sarıgedik), H.28 (Koç), H.29 (Bekçi), H.30-31 (Özçoban), H.32-33-34 (Irak), H.36-37-38 (Sokun), H.39 -41 (Irgat), H.44 (Heydeci), H.45 (Çelegen), H.46-47 (Çukurderesi), H.49 (Çayırlık), H.50 (K1z1l), H.51 (Kazar), H.52-58 (Koruluk), H.53 (Yurt), H.54-55 (Çiloğlu), H.57 (Uzgur)'dur.

Bazı hanelerin kayıtları "kapalı kayıt" konumundadır. (\% 24.13) Bu haneler şunlar: H.5-9-13-14-17-25-26-27-35-40-42-43-48-56'dır. Bazı haneler idari birimden başka bir idari birime yer değiştirerek kapalı kayıt konumundadır.( \% 8.62) Bu haneler şunlardır: H.2 (Alanköy), H.16-47 (Turgutlu), H.54 (Gaziler Köyü), H.57 (Falaka Köyü)'dür. Bazı hanelerdeki kişilerin bazısı başka bir idari birime yer değiştirerek kaydını aldırmışlardır. (\% 20.68) Bu haneler şunlardır: H.1-18-19-20-21-29-5051-52 (Turgutlu), H.8 (Falaka Köyü), H.32 (Ödemiş), H.34 (Kabaağaç Köyü- Turgutlu)'dur. Hanelerin defterdeki lakapları ile örtüşen soyadları şunlardır: H.5 Başoğlu (Başoğlu), H.12 Karabacakoğlu (Karabacak), H.26 Sivrioğlu (Sivrioğlu), H.28 Koçoğlu (Koç), H.30 Çobanoğlu (Özçoban), H.31 Özçobanoğlu (Özçoban), H.54-55 Çiloğlan (Çiloğlu), H.56 Çağlıoğlu (Çağlı)'dır. Hanelerin aldığı soyadları ile bugün idari birimdeki lakapları örtüşenler şunlardır: H.13 Bacak (Bacaklar), H.30-31 Özçoban (Çobanoğlu), H.44 Hedeyci (Hedeyciler)'dir. 1320 yazımındaki kişilerin cinsiyet durumları: Yazımı yapılan 328 kişiden 159 kişi erkek (\% 48.47), 169 kişisi (\% 51.52 ) ise bayandır. 1320 yazımındaki kişilerin medeni durumları: Yazımı yapılan 328 kişiden 144 kişi ( $\%$ 43.90) evli, 165 kişi (\% 50.30) bekâr ve 19 kişisi (\% 5.80) duldur.

Kızılkeçili'nin tespit edebildiğimiz bilinen nüfus sayım sonuçları şöyledir. ${ }^{31}$

\begin{tabular}{|c|c|c|c|c|c|c|c|c|c|c|c|c|c|c|c|c|}
\hline$\underset{\infty}{\infty}$ & 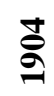 & ָิ & బొ & 옴 & $\frac{10}{2}$ & $\begin{array}{l}\text { ำ } \\
2\end{array}$ & $\begin{array}{l}1 \\
2 \\
2\end{array}$ & 응 & $\begin{array}{l}10 \\
2 \\
2\end{array}$ & $\begin{array}{c}2 \\
2 \\
2\end{array}$ & $\begin{array}{l}n \\
0 \\
2\end{array}$ & $\begin{array}{l}\stackrel{8}{\mathscr{0}} \\
\stackrel{-}{2}\end{array}$ & $\begin{array}{l}\mathscr{0} \\
\mathscr{2}\end{array}$ & ڤ్ & $\hat{\sigma}$ & ฮ్ \\
\hline 2 & 3 & 3 & 3 & 4 & 3 & 4 & 3 & 4 & 5 & 4 & 5 & 5 & 4 & 6 & 6 & 6 \\
\hline 3 & 2 & 0 & 8 & 0 & 7 & 0 & 9 & 5 & 0 & 9 & 1 & 2 & 5 & 1 & 2 & 7 \\
\hline 7 & 8 & 0 & 1 & 4 & 6 & 7 & 8 & 9 & 0 & 8 & 6 & 5 & 2 & 2 & 7 & 7 \\
\hline
\end{tabular}

\footnotetext{
${ }^{31}$ Sadiye Tutsak, T.29 Mali 1307 (1891 miladi) Yll Aydın Vilayet Salnamesi Cilt 2, Ege Üniversitesi Edebiyat Fakültesi Tarih Bölümü Yayımlanmamış Bitirme Tezi, 1988.

${ }^{32}$ Erkan Serçe, 1923 Senesi İzmir Vilayet İstatistiği, Cilt. 1, İzmir Büyükşehir Belediyesi Yayınları, İzmir 2001, s. 16-17.
} 


\section{Necat ÇETIN}

Köy sayım Kaynakları: 2008 yılı TÜIKK adrese dayalı nüfus kayıt sistemi nüfus sayımı sonuçlarına göre 336 erkek, 322 kadın olmak üzere toplam 658 kişi nüfus vardır ${ }^{33}$.

\section{SONUC}

1071 Malazgirt Savaş'ından sonra Anadolu'ya başlayan göçler ile birlikte Oğuzların Üçok kolunun Dağ Han soyundan Salur boyuna mensup olan Kızılkeçeli aşireti de Anadolu'ya gelmişlerdir. Aşiret Anadolu'ya geldikten sonra çeşitli bölgelere taşınmıştır. Bunlar arasında Çorum sancağı, Biga sancağ 1 Ezine kazazı, Kars-1 Maraş sancağı ve Saruhan sancakları bulunmaktadır. Günümüzde aşiretin yaşam sürdüğü Anadolu'da bazı bölgelerde Kızılkeçeli adından köyler bulunmaktadır. Çalışmamızın konusu olan İzmir ili Bayındır ilçesi Kızılkeçeli köy’ü de bunlardan biridir.

Köyün Osmanlı'nın ilk nüfus sayımı olan 1320 tarihli nüfus defterinde hane sayısı 58'dir. Yaptığım çalışmada köydeki hane sayısı, nüfus, hane reislerinin lakapları, köyde doğanların sayısı, ölü sayısı verilmiştir. Ayıca Kızılkeçeli köyünün miladi 1891-2000 yılları arasında nüfus'u da çıkarılmıştır.

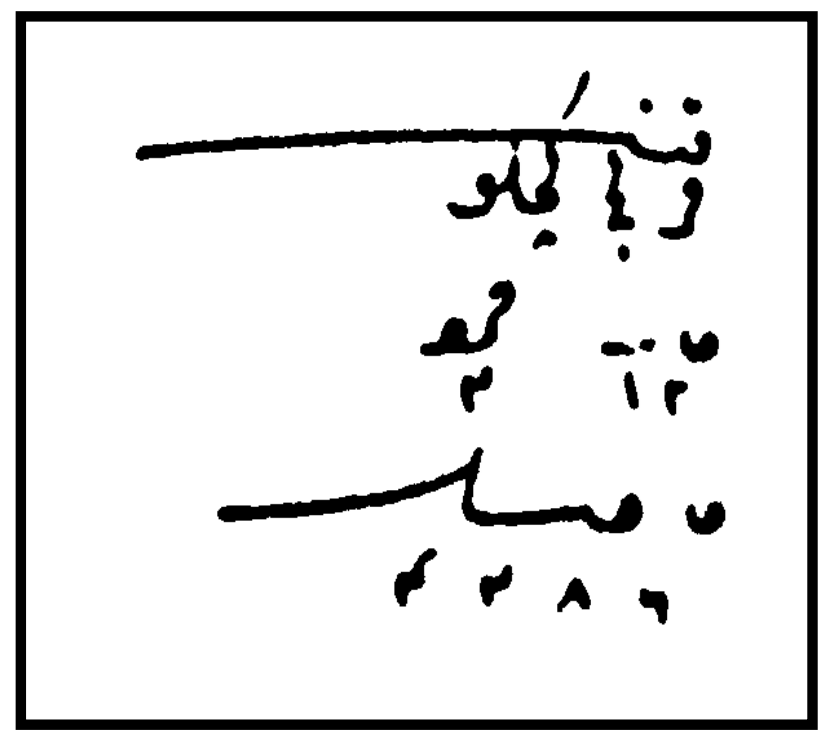

\footnotetext{
${ }^{33}$ İlgili yılların Genel Nüfus Sayımları (TUiK Bölge Müdürlüğü Kütüphanesi).
} 
Bayındır Kızılkeçili Köyünde Rumi 1320 Yılı Son Nüfus Tahriri

Bayındır Kızılkeçili Köyünde Rumi 1320 Yılı Son Nüfus Tahriri

\begin{tabular}{|c|c|c|c|c|c|c|c|}
\hline \multirow{16}{*}{ 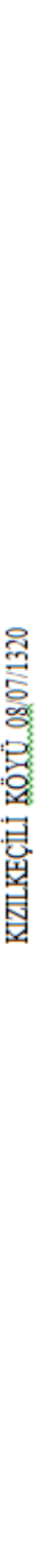 } & {$\left[\mathrm{m}_{\mathrm{C}}\right.$} & & & & $\rightarrow$ & & \\
\hline & 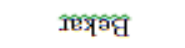 & a & $m$ & 一 & N & $m$ & $\rightarrow$ \\
\hline & !ฺ & 0 & a & + & N & $\mathrm{d}$ & $\nabla$ \\
\hline & итре प्र & $m$ & $\rightarrow$ & $m$ & + & + & d \\
\hline & хәхуг⿴囗十 & n & $\nabla$ & $a$ & $\longrightarrow$ & 一 & $\mathrm{m}$ \\
\hline & вuाE[प्राऽ́V & 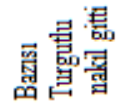 & 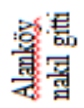 & & & 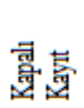 & \\
\hline & dexe' & 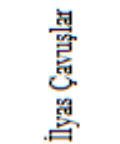 & 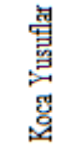 & 意密 & 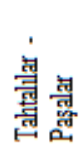 & & 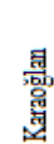 \\
\hline & IsLKE & $\infty$ & $n$ & n & $n$ & $n$ & n \\
\hline & четре & 受 & $\begin{array}{l}\text { 总 } \\
\text { 总 } \\
\text { 恶 }\end{array}$ & 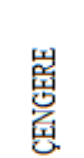 & 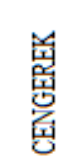 & 号 & 息 \\
\hline & $\operatorname{Iste} e_{\lambda}$ uाze $\lambda$ & $m$ & 요 & 于 & 웅 & n & 웅 \\
\hline & 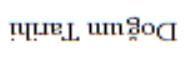 & ప్తి & 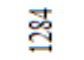 & $\stackrel{\infty}{\Xi}$ & ఫ్ & ్ֶతి & ఖ్తి \\
\hline & ṭaxumsod & 莺 & 莬 & 蒷 & 昜 & 菄 & 营 \\
\hline & Issauuv & 䚓 & 首 & 巊 & 貣 & 缾 & 䙷 \\
\hline & Iseqeq & 窇 & 寻 & 灵 & 光 & $\begin{array}{l}\text { 盢 } \\
\text { 量 }\end{array}$ & 岁 \\
\hline & uṇș & 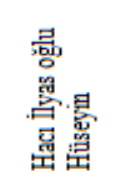 & 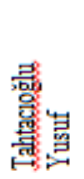 & 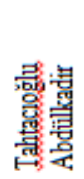 & 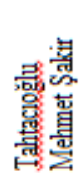 & 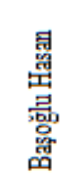 & 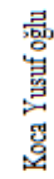 \\
\hline & оน аиен & $\rightarrow$ & a & $\mathrm{m}$ & + & n & 0 \\
\hline
\end{tabular}




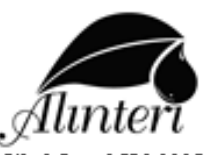

Cilt:1 Sayn:2 Yll:2017

Bayındır Kızılkeçili Köyünde Rumi 1320 Yılı Son Nüfus Tahriri

\begin{tabular}{|c|c|c|c|c|c|c|c|c|}
\hline & - & $\rightarrow$ & - & & $\rightarrow$ & & & \\
\hline & $\rightarrow$ & $\sim$ & $\rightarrow$ & in & $\sim$ & $\rightarrow$ & $\rightarrow$ & $\rightarrow$ \\
\hline & $\sim$ & $r$ & $\sim$ & $m$ & $\sim$ & $\sim$ & $\sim$ & $\sim$ \\
\hline & $\mathrm{m}$ & + & m & $\mathrm{m}$ & + & $\sim$ & $\sim$ & $\rightarrow$ \\
\hline & - & 0 & $\rightarrow$ & in & - & - & $\rightarrow$ & $\sim$ \\
\hline & & 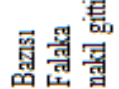 & 营芙 & & & & 营葛 & 葋䓪 \\
\hline 釦 & 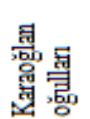 & 鸹 & 韋 & $\begin{array}{l}\text { 賞 } \\
\text { 昜 } \\
\text { 䓪 }\end{array}$ & $\begin{array}{l}\text { 蕒 } \\
\text { 昜 } \\
\end{array}$ & $\begin{array}{l}\text { 竞 } \\
\text { : }\end{array}$ & $\begin{array}{l}\text { 夠 } \\
\text { 邑 }\end{array}$ & \\
\hline & $\theta$ & 으 & + & $\infty$ & $n$ & $\mathrm{~m}$ & $\mathrm{~m}$ & $m$ \\
\hline & 恖 & 悬 & 愳 & 总 & 总 & $\begin{array}{l}\text { 岂 } \\
\text { 䍃 } \\
\text { 変 }\end{array}$ & 息 & \\
\hline & in & $\vec{m}$ & r & 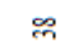 & $\overrightarrow{\mathrm{m}}$ & m & 잉 & भ \\
\hline & 丞 & ‡్త & $\stackrel{m}{g}$ & శ్తే & తి & జే & 壱 & $\underline{\Xi}$ \\
\hline & 貣 & 青 & 青 & 寻 & 費 & 費 & 輲 & 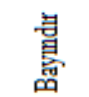 \\
\hline & 買 & 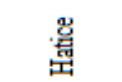 & 穿 & 首 & 貝 & 貣 & 貣 & 穿 \\
\hline & 䍖 & 毒 & 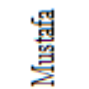 & 壱 & 柔 & 䏝 & 易 & 冝 \\
\hline 甚 & 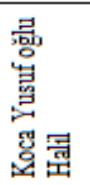 & 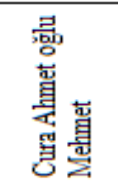 & 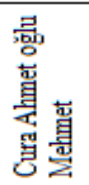 & 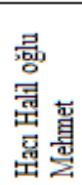 & 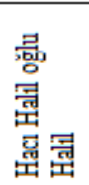 & 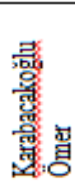 & 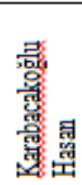 & 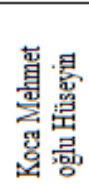 \\
\hline & $r$ & $\infty$ & a & 으 & $\Rightarrow$ & $\simeq$ & $\cong$ & $\Xi$ \\
\hline
\end{tabular}




\begin{tabular}{|c|c|c|c|c|c|c|}
\hline - & & & & $\rightarrow$ & & - \\
\hline N & $\sim$ & en & $n$ & $r$ & ๑ & $\nabla$ \\
\hline$\sim$ & $\sim$ & $\sim$ & $\sim$ & 0 & $\nabla$ & $\sim$ \\
\hline$m$ & $\sim$ & $\nabla$ & en & in & 0 & $\nabla$ \\
\hline \multirow[t]{2}{*}{$\sim$} & $\sim$ & - & $\nabla$ & a & $\nabla$ & $m$ \\
\hline & 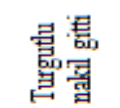 & 寻春 & 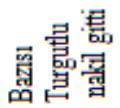 & 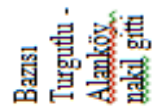 & 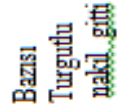 & 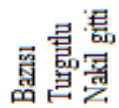 \\
\hline $\begin{array}{l}\text { 或 } \\
\text { 葋 } \\
\text { 吉 } \\
\stackrel{5}{9}\end{array}$ & 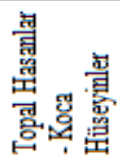 & & 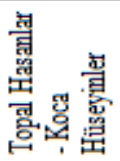 & 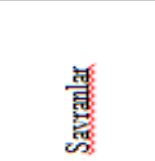 & 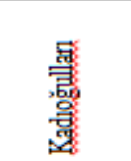 & 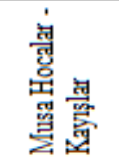 \\
\hline$n$ & + & in & $r$ & 士 & 으 & $r$ \\
\hline 总 & 学 & & 息 & 兊 & 兌 & 意 \\
\hline$:>$ & ন & 요 & $\vec{m}$ & ஓ & 6 & $\stackrel{\curvearrowleft}{\curvearrowleft}$ \\
\hline 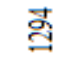 & ஜ్ֶ & $\vec{\Xi}$ & ‡్త & 웜 & 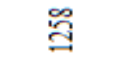 & త్రి \\
\hline 寻 & 巻 & 昜 & 昜 & 寻 & 礐 & 莺 \\
\hline 莺 & $\begin{array}{l}\text { 营 } \\
\text { 空 }\end{array}$ & 莬 & 总 & $\begin{array}{l}\text { 岁 } \\
\text { 密 }\end{array}$ & 貣 & 䉕 \\
\hline 䅈 & $\begin{array}{l}\text { 㬏 } \\
\text { 兑 }\end{array}$ & $\begin{array}{l}\text { 量 } \\
\text { 急 }\end{array}$ & $\begin{array}{l}\text { 量 } \\
\text { 急 }\end{array}$ & 㐘 & 貣 & $\begin{array}{l}\text { 䁃 } \\
\text { 营 }\end{array}$ \\
\hline 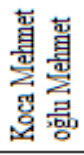 & 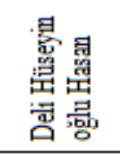 & 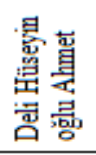 & 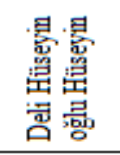 & 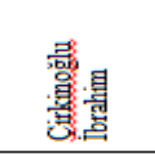 & 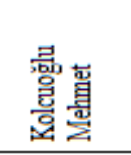 & 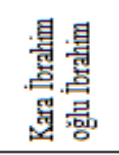 \\
\hline$\cong$ & 으 & $\Xi$ & $\stackrel{\infty}{=}$ & 으 & 이 & $\vec{\nabla}$ \\
\hline
\end{tabular}




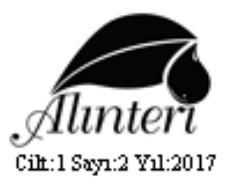

$1-23$

Necat ÇETIN

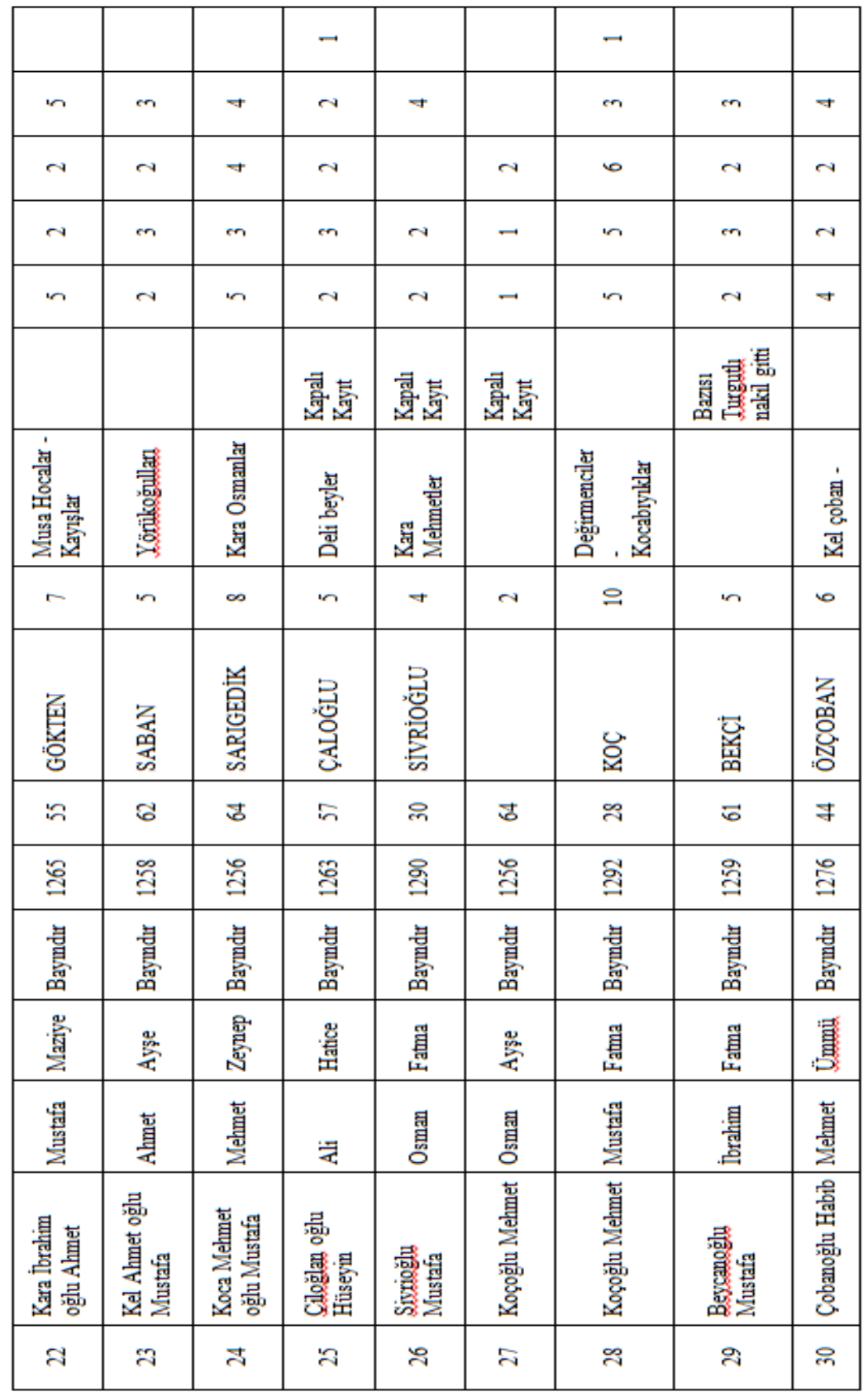




\begin{tabular}{|c|c|c|c|c|c|c|c|}
\hline & - & $\nabla$ & $\nabla$ & & $d$ & & $\rightarrow$ \\
\hline & N & N & N & $\nabla$ & $d$ & $\sim$ & $\sim$ \\
\hline & $\rightarrow$ & $\sim$ & $\mathrm{m}$ & - & $d$ & $\rightarrow$ & d \\
\hline & $d$ & $\nabla$ & $\mathrm{m}$ & $m$ & $d$ & - & $\rightarrow$ \\
\hline & & 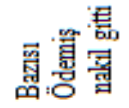 & & 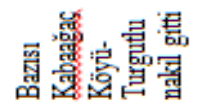 & 鴶营 & & \\
\hline 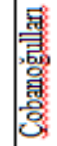 & 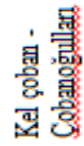 & 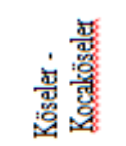 & 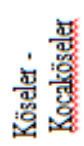 & 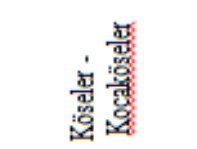 & & 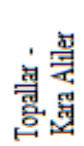 & 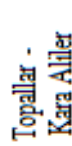 \\
\hline & $m$ & 0 & 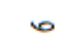 & + & $\nabla$ & $\sim$ & $\mathrm{m}$ \\
\hline & $\begin{array}{l}\text { 学 } \\
\text { 兽 }\end{array}$ & 学 & 学 & 总 & $\begin{array}{l}\text { 㥕 } \\
\text { 灵 }\end{array}$ & 㫘 & 总 \\
\hline & 으 & '马 & ๆ & નె & 8 & $\vec{\nabla}$ & i \\
\hline & 을 & 气ิ & $\Xi$ & 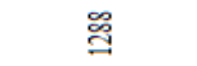 & ฮิ & 总 & 志 \\
\hline & 暍 & 莺 & 寥 & 莺 & $\begin{array}{l}\text { 寻 } \\
\text { 牟 } \\
\end{array}$ & 昜 & 䄰 \\
\hline & $\begin{array}{l}\text { 苟 } \\
\text { 密 }\end{array}$ & 貣 & 貣 & 萦 & 萦 & 䆓 & 買 \\
\hline & $\begin{array}{l}\text { 曷 } \\
\text { 兑 } \\
\text { 䍃 }\end{array}$ & 安 & 灵 & 睍 & 盇 & 莧 & 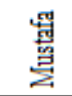 \\
\hline & 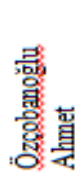 & 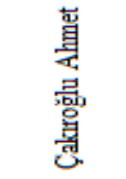 & 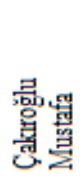 & 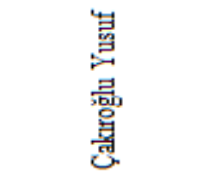 & 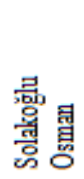 & 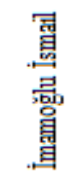 & 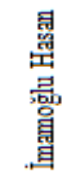 \\
\hline & $\vec{m}$ & ને & $m$ & 点 & $\mathrm{m}$ & in & $\bar{n}$ \\
\hline
\end{tabular}




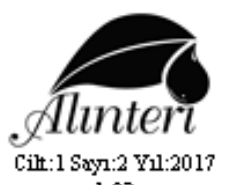

1.23

\begin{tabular}{|c|c|c|c|c|c|c|c|c|}
\hline 一 & 一 & 一 & & & & & 一 & \\
\hline \multirow[t]{2}{*}{+} & $\nabla$ & $n$ & $\nabla$ & $\rightarrow$ & $\rightarrow$ & $m$ & + & + \\
\hline & & $\sim$ & $\sim$ & $\sim$ & $N$ & N & & $d$ \\
\hline $\mathrm{m}$ & $\mathrm{m}$ & $r$ & + & $\rightarrow$ & $\rightarrow$ & $d$ & $d$ & $\sim$ \\
\hline \multirow[t]{2}{*}{$\sim$} & $\sim$ & 一 & $\sim$ & $\sim$ & $\sim$ & $m$ & $m$ & $\nabla$ \\
\hline & & 胥䒸 & & 蒷营 & 胥䒸 & & & \\
\hline 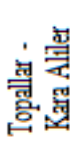 & 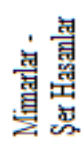 & 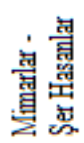 & 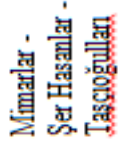 & $\begin{array}{l}\frac{a}{3} \\
\frac{3}{3} \\
\frac{3}{0}\end{array}$ & $\frac{\frac{3}{2}}{\frac{3}{3}}$ & 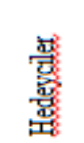 & 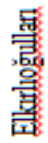 & $\begin{array}{l}\text { 莧 } \\
\text { 貟 }\end{array}$ \\
\hline$n$ & $n$ & $\infty$ & 0 & $\mathrm{~m}$ & $m$ & in & $n$ & ๑ \\
\hline 㶪 & 苞 & 息 & 恚 & 若 & 总 & $\begin{array}{l}\text { 它 } \\
\text { 琶 }\end{array}$ & 哥 & 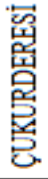 \\
\hline$\Xi$ & $\infty$ & $\mathcal{F}$ & ๓n & $\not 3$ & 7 & 9 & gi & 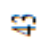 \\
\hline 总 & శ్రి & $\stackrel{\infty}{\text { తn }}$ & ळ్తి & อี & 을 & త్ & $\overrightarrow{\mathrm{g}}$ & $\Xi$ \\
\hline 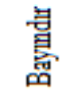 & $\begin{array}{l}\text { 寻 } \\
\text { 窇 }\end{array}$ & $\begin{array}{l}\text { 葛 } \\
\text { 盟 }\end{array}$ & $\begin{array}{l}\text { 营 } \\
\text { 畣 }\end{array}$ & $\begin{array}{l}\text { 蔓 } \\
\text { 总 }\end{array}$ & $\begin{array}{l}\text { 葛 } \\
\text { 苟 }\end{array}$ & $\begin{array}{l}\text { 营 } \\
\text { 昜 }\end{array}$ & 寻 & 寻 \\
\hline 兑 & 鼻 & 買 & 莺 & 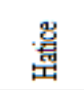 & 萦 & 労 & 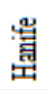 & $\stackrel{\text { 慁 }}{\stackrel{5}{\mathrm{~s}}}$ \\
\hline $\begin{array}{l}\text { 睍 } \\
\end{array}$ & 具 & $\begin{array}{l}\text { 昜 } \\
\text { 莹 }\end{array}$ & 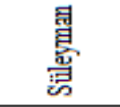 & $\begin{array}{l}\text { 睍 } \\
\end{array}$ & 表 & $\begin{array}{l}\text { 睍 } \\
\end{array}$ & 光 & $\begin{array}{l}\text { 悬 } \\
\text { 范 }\end{array}$ \\
\hline 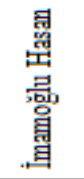 & $\begin{array}{l}\text { 搨 } \\
\text { 总責 } \\
\text { 夏 }\end{array}$ & $\begin{array}{l}\text { 㫛 } \\
\text { 夏罯 } \\
\text { 量 }\end{array}$ & 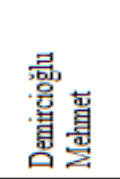 & 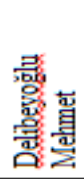 & 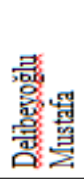 & $\begin{array}{l}\text { 哥 } \\
\text { 㺃尊 } \\
\text { 罖 }\end{array}$ & 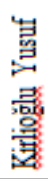 & 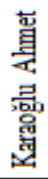 \\
\hline m & 요 & P & $F$ & $\mathcal{F}$ & q & F & '? & 웅 \\
\hline
\end{tabular}




\begin{tabular}{|c|c|c|c|c|c|c|}
\hline & $\rightarrow$ & & $\rightarrow$ & $\rightarrow$ & & \\
\hline$\nabla$ & $\rightarrow$ & $m$ & en & $\sim$ & $n$ & $\infty$ \\
\hline$\nabla$ & & + & $\sim$ & $\sim$ & $\nabla$ & 0 \\
\hline$\nabla$ & $\rightarrow$ & $m$ & $m$ & $\sim$ & $n$ & $\infty$ \\
\hline$\nabla$ & $\rightarrow$ & + & $m$ & $m$ & $\nabla$ & 0 \\
\hline 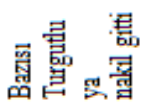 & 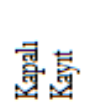 & & 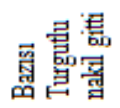 & 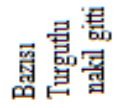 & 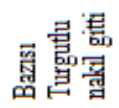 & \\
\hline 䆩 & & 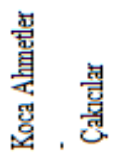 & 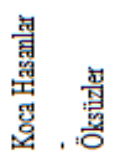 & 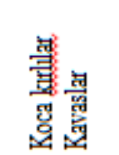 & 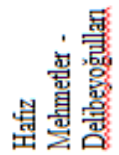 & $\begin{array}{l}\text { 顡 } \\
\text { 畜 } \\
\text { 童 }\end{array}$ \\
\hline$\infty$ & N & r & 0 & n & a. & 士 \\
\hline 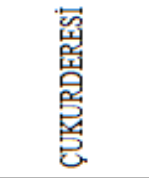 & & 䁘 & 圈 & 采 & 貪 & 占 \\
\hline 요 & J & 6 & m & ' & 6 & 于 \\
\hline $\overrightarrow{\Xi ્ ٍ ~}$ & 号 & 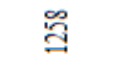 & ప్త & '气 & '气 & $\widetilde{\Xi}$ \\
\hline $\begin{array}{l}\text { 䒴 } \\
\text { 昜 }\end{array}$ & $\begin{array}{l}\text { 悬 } \\
\text { 弇 }\end{array}$ & 責 & $\begin{array}{l}\text { 䒴 } \\
\text { 昜 }\end{array}$ & 营 & 营 & 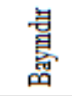 \\
\hline 悬 & 䙷 & 睍 & 貣 & 粍 & 萦 & $\begin{array}{l}\text { 营 } \\
\text { 密 }\end{array}$ \\
\hline $\begin{array}{l}\text { 覟 } \\
\text { 营 }\end{array}$ & $\begin{array}{l}\text { 睍 } \\
\text { 帘 }\end{array}$ & $\begin{array}{l}\text { 夏 } \\
\text { 堂 }\end{array}$ & 盇 & 悬 & $\begin{array}{l}\text { 嗬 } \\
\text { 量 } \\
\end{array}$ & 空 \\
\hline 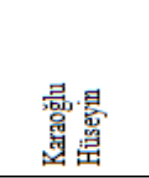 & 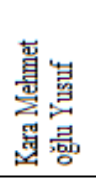 & 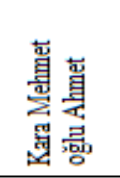 & 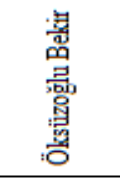 & 㐁 & 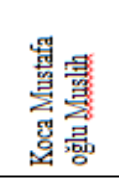 & 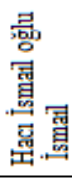 \\
\hline 7 & 古 & of & 므 & $\vec{\imath}$ & ন & ๓ \\
\hline
\end{tabular}




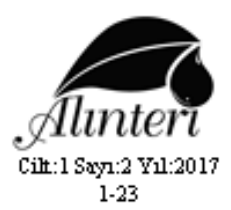

ISSH:2564-6583

e-ISSH: 2602-229X

Necat ÇETIN

\begin{tabular}{|c|c|c|c|c|c|c|c|}
\hline & & & - & - & 으 & & \\
\hline$m$ & $\infty$ & - & $\rightarrow$ & - & 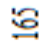 & & \\
\hline$\sim$ & $m$ & $\sim$ & $m$ & & 寻 & & \\
\hline - & a. & $\sim$ & $\mathrm{m}$ & - & 응 & & \\
\hline$\checkmark$ & $\sim$ & - & $\sim$ & - & $\stackrel{\text { 号 }}{=}$ & & \multirow{2}{*}{ 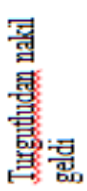 } \\
\hline 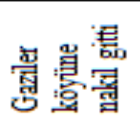 & & 慁雷 & 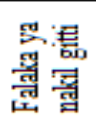 & & \multirow{2}{*}{ 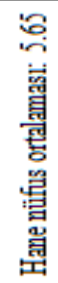 } & & \\
\hline $\begin{array}{l}\text { 竇 } \\
\text { 空 }\end{array}$ & $\begin{array}{l}\text { 䆵 } \\
\text { 㲘 }\end{array}$ & $\frac{\text { 咅 }}{\frac{3}{5}}$ & & 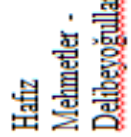 & & & 莧 \\
\hline$n$ & $=$ & $m$ & $n$ & $\sim$ & శ్ & & \\
\hline $\begin{array}{l}\text { 寻 } \\
\text { 寻 }\end{array}$ & $\begin{array}{l}\text { 룽 } \\
\text { 晃 }\end{array}$ & 哭 & 号 & 岁 & 寰 & & 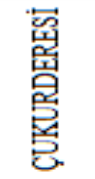 \\
\hline$\curvearrowleft$ & $\vec{c}$ & 으 & $\approx$ & 으 & $\stackrel{?}{7}$ & & \\
\hline త & ఏ్త & 옳 & ్ㅗ & 을 & \multirow{3}{*}{ 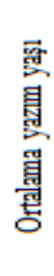 } & & 怘 \\
\hline 寻 & 寻 & 責 & 寻 & 寻 & & & 寻 \\
\hline 缶 & 窉 & 帚 & 貣 & 貣 & & & 罿 \\
\hline 貣 & 貣 & 表 & $\bar{z}$ & 罍 & & & $\begin{array}{l}\text { 最 } \\
\text { 兽 }\end{array}$ \\
\hline 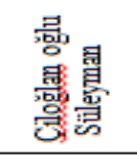 & $\begin{array}{l}\text { 品 } \\
\text { 惑㯰 } \\
\text { 竞 }\end{array}$ & 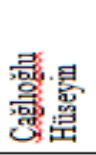 & 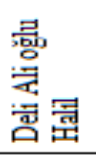 & 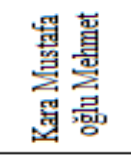 & & Љ & $\begin{array}{l}\text { 临 } \\
\text { 急 }\end{array}$ \\
\hline$\stackrel{口}{ }$ & $\curvearrowleft$ & $\therefore$ & $\approx$ & $\stackrel{\curvearrowleft}{\curvearrowleft}$ & & & 욤 \\
\hline
\end{tabular}




\section{KAYNAKÇA}

116 Numarall Muhasebe-i Vilayet-i Anadolu Defteri (937/1530). Başbakanlık Devlet Arşivleri Genel Müdürlüğü Yayınları, Ankara 1995.

Akbayar, Nuri, “Tanzimat'tan Sonra Osmanlı Devlet'i Nüfusu”, Tanzimat'tan Cumhuriyete Türkiye Ansiklopedisi, C. 5, İstanbul İletişim Yayınları, 1983.

Akkuş, Tacettin, Tanzimat Başlarında Balıkesir Kazası (18401845), Zağnos Kültür ve Eğitim Vakfı, Balıkesir 2001.

Aydın, Mahir, "Sultan II. Mahmut Döneminde Yapılan Nüfus Tahrirleri”, Sultan II. Mahmut Reformlart Semineri 28-30 Haziran 1989, İstanbul 1990.

Çadırc1, Musa, Tanzimat Döneminde Anadolu Kentlerinin Sosyal ve Ekonomik Yapısı, TTK, Ankara 1997.

Doğru, Halime, "Osmanlı Devletinde Toprak Yazımından Nüfus Sayımına Geçiş ve Bir Nüfus Yoklama Defteri Örneği”, Anadolu Üniversitesi Fen-Edebiyat Fakültesi Dergisi, C. 1, S. 2, Eskişehir 1989.

Halaçoğlu, Yusuf, Anadolu'da Aşiretler Cemaatlar Oymaklar (1453-1650), 6. Cilt, TTK, Ankara 2009.

Karal, Z. Enver, Osmanlı İmparatorluğu'nda İlk Nüfus Sayımı 1831, Başbakanlık Yayınları, Ankara 1943.

Kızılkeçili Köyü Muhtarlık Arşivi Köy Nüfus Esas Defteri.

Lütfi Tarihi, Cilt: 1, Yapı Kredi Yayınları, İstanbul 1999.

Necat Çetin Özel Arşivi

Nüfus Sicil Nizamnamesi, Dersaadet, 1316.

Salur, S. Faruk, TDV İslam Ansiklopedisi, Cilt: 36, TDV Yayınları, Ankara, 2009.

Sarıcaoğlu, E. Mehmet, Milli Tarih Açısından Osmanlı Devleti'nde Merkez Taşra İlişkileri, Kültür Bakanlığı Yayınları, Ankara 2001.

Serçe, Erkan, 1923 Senesi İzmir Vilayet İstatistiği, Cilt: 1, İzmir Büyükşehir Belediyesi Yayınları, İzmir 2001. 


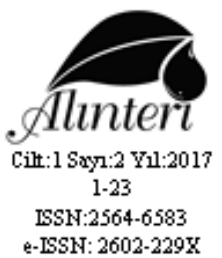

Necat ÇETIN

Sertoğlu, Midhat, Osmanlı Tarih Lûgatı, Enderun Kitapevi, İstanbul 1986.

Tutsak, Sadiye, T.29 Mali 1307 (1891 Miladi) Yılı Aydın Vilayet Salnamesi Cilt 2, Ege Üniversitesi Edebiyat Fakültesi Tarih Bölümü Yayımlanmamış Bitirme Tezi, 1988. 
Bayındır Kızılkeçili Köyünde Rumi 1320 Yılı Son Nüfus Tahriri

EK: 1

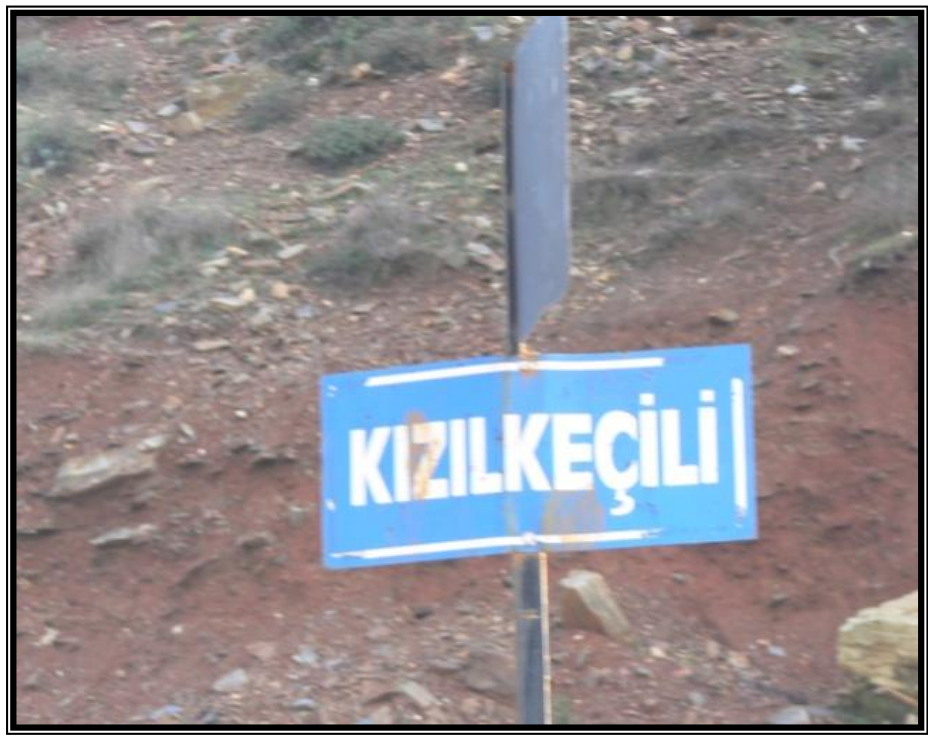

EK: 2

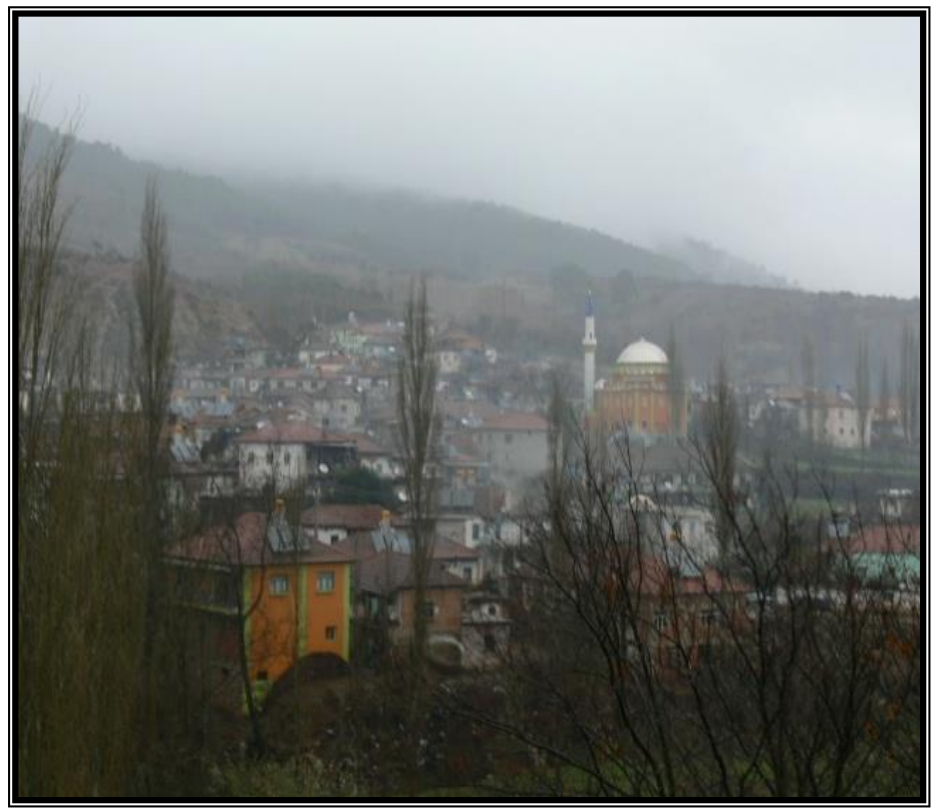


Alinteri

1.23

ISSH:2564-6583

e-ISSH: $2602-229 \mathrm{X}$

Necat ÇETÍN

EK: 3

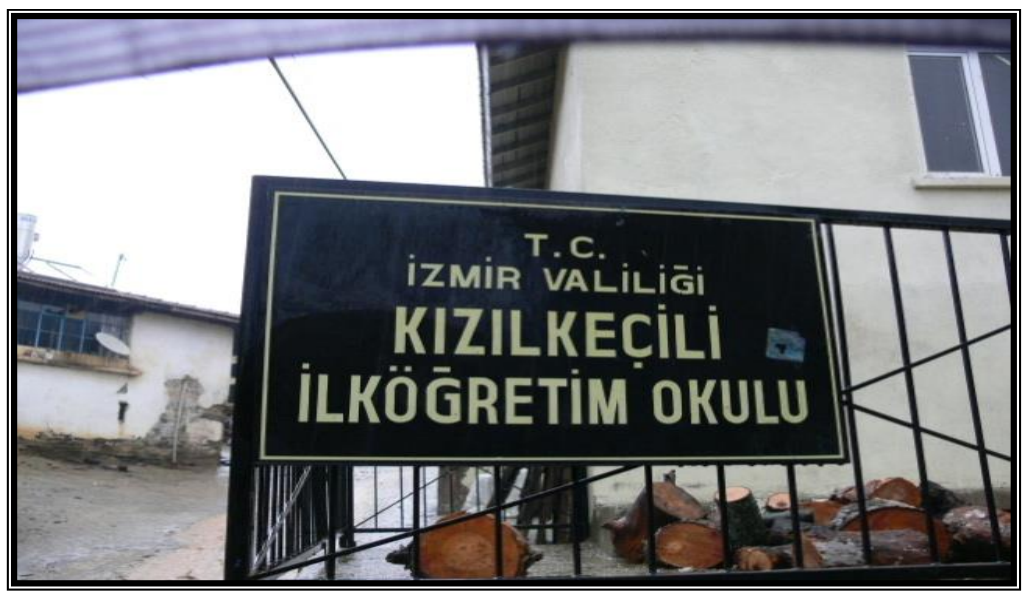

EK: 4

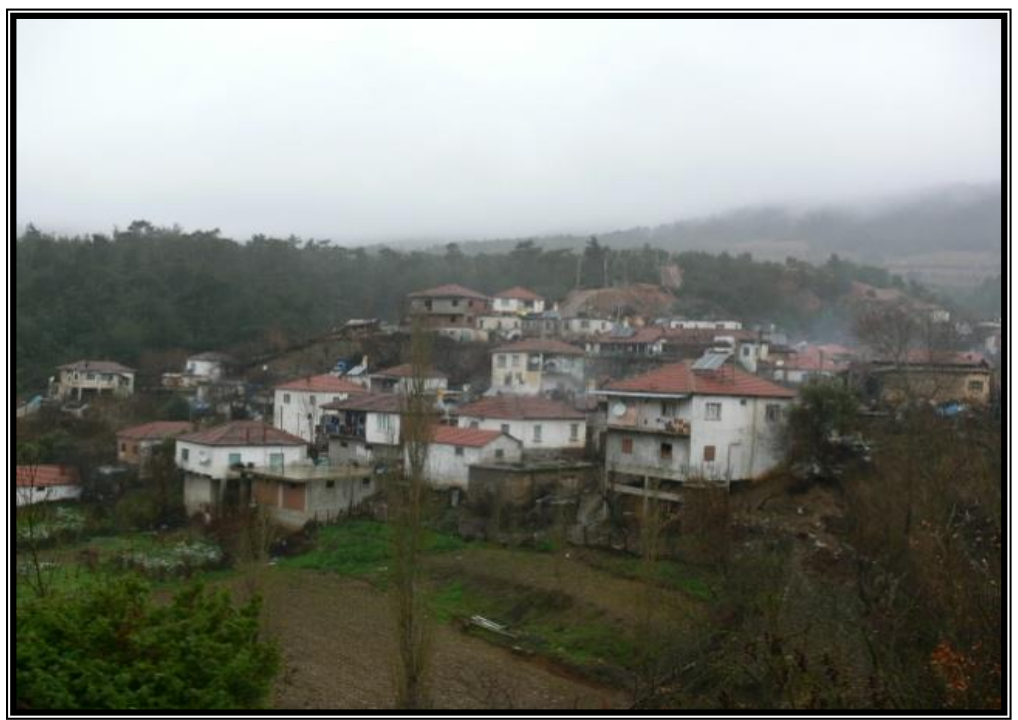


Bayındır Kızılkeçili Köyünde Rumi 1320 Yılı Son Nüfus Tahriri

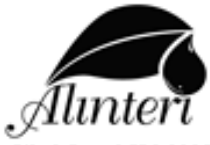

\section{EK: 5}

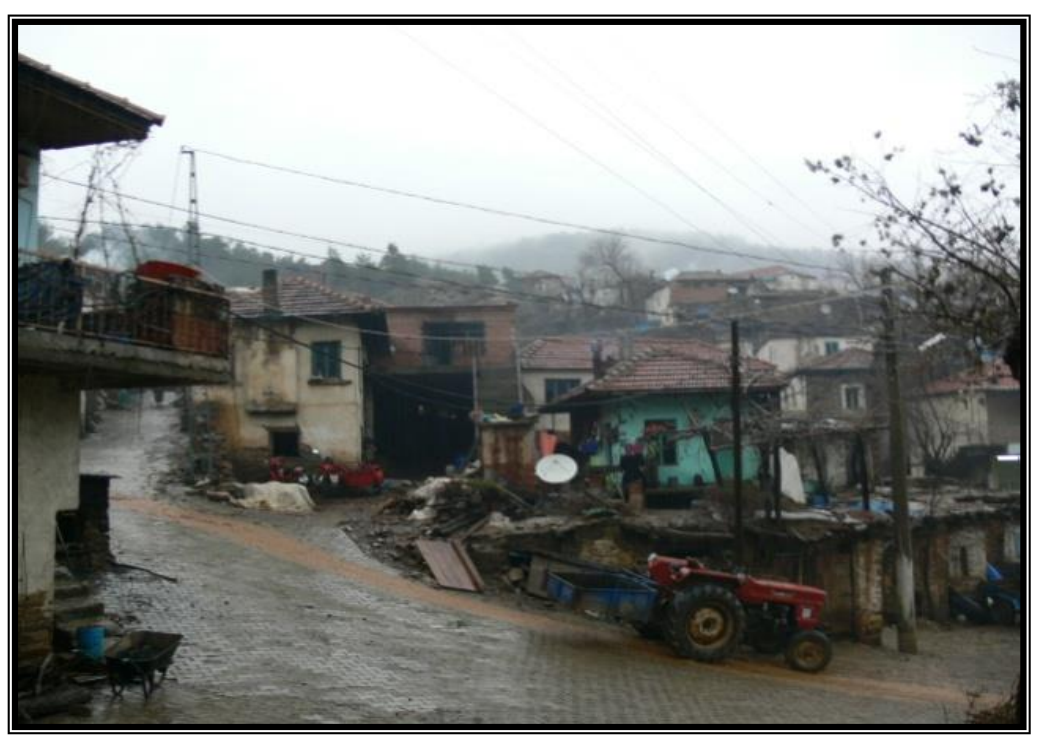

EK: 6

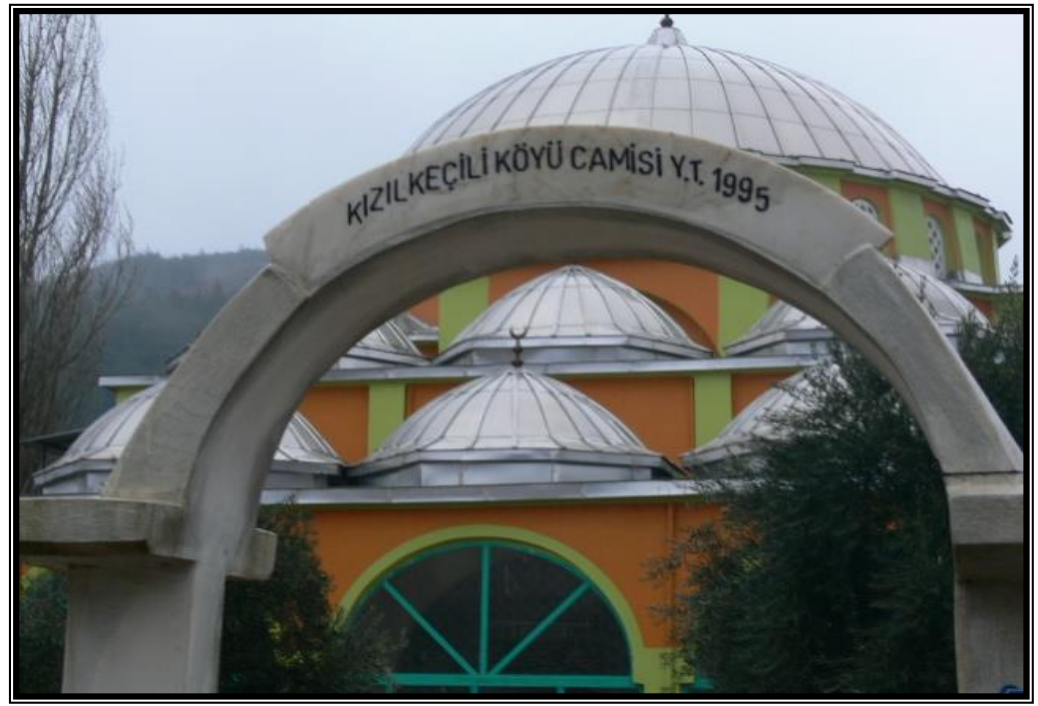


